\title{
Protecting Stone Fruit Flower Buds from Winter Freeze Damage
}

\author{
M.J. Willett ${ }^{1}$, E.L. Proebsting ${ }^{2}$, and R.E. Redman III $^{3}$
}

Additional index words. critical temperatures, simulation, dormant, forecast, peach, apricot, sweet cherry

Summary. Flower buds of peach, apricot, and sweet cherry are killed by low temperatures during winter and spring. Frost protection measures used commonly in the spring are applied to freeze protection during the winter in the Yakima Valley of Washington. Critical temperatures change rapidly during winter. To succeed, winter freeze protection requires adequate inversions, equipment that operates at temperatures below $-15 \mathrm{C}$, and reliable estimates of critical temperatures for flower bud survival. Observations and experience have shown that inversions develop on most critical winter nights. Wind machines and orchard heaters will operate under severe low-temperamre conditions. Winter freeze protection has been practiced successfully on an increasing scale in the Yakima Valley for more than 20 years. Five packinghouses operate laboratories to measure critical temperatures. A computer model that estimates critical temperatures from daily or hourly air temperatures is being incorporated into these estimates.

n central Washington the yearly value of stone fruit production approaches $\$ 80$ million, with sweet cherries the most important species (Fitch, 1992 ). The acreage of stone fruits (Table 1 ) is small compared to the apple industry, but valuable to regional orchard diversification.

Stone fruit yields in Washington vary widely from year to year (Figs. 1-3). Low-temperature injury is the primary cause of these fluctuations. Injury may occur in spring or during winter. Winter freezes cause the most devastating losses and can virtually eliminate the crop statewide, as occurred in 1965. The three species react differently in different years. These differences are readily explained by applying the principles that govern changes in flower bud hardiness (Andrews and Proebsting, 1987; Proebsting, 1963). Only in 1965 were yields of all three species seriously reduced in the same year. Other production problems that present comparably serious threats to the industry are controlled satisfactorily, except for rain cracking of sweet cherry fruit.

${ }^{1}$ Area Tree Fruit Agent, Washington State University Cooperative Extension, 128 N. 2nd St., Yakima, WA 98901.

${ }^{2}$ Horticulturist, WSU Irrigated Agriculture Research and Extension Center, Prosser, WA 99350.

${ }^{3}$ Owner/Operator, R. E. Redman and Sons, Wapato, WA 98951.

The cost of publishing this paper was defrayed in part by the payment of page charges. Under postal regulations this paper therefore must be hereby marked advetisement solely to indicate this fact. 
Obviously, large crop loss can mean severe economic losses for individual growers, but other less-tangible losses can also occur. Because production and distribution of most stone fruits is in the hands of a relatively small number of private and cooperative packinghouses, crop loss to freeze damage can mean loss of marketing niches. Uniform annual cropping is a marketing imperative (Willett and Peterson, 1987).

Over the years, the central Washington fruit industry has invested significantly in measures to protect the crop from spring frost. Wind machines, heaters, and sprinklers are used individually and in combinations to maintain flower buds above critical temperatures in the orchard (Ballard and Proebsting, 1978). A complex infrastructure has developed to supply, service, and fuel these devices.

With valuable commodities. such as stone fruits, the annual threat of freeze damage and the methods available to raise tissue temperatures, it was logical to consider using orchard heating during the winter-in spite of several factors that seem to make such an operation illogical. First, flower bud critical temperatures were unknown and varied daily. Secend. it was believed that inversions did not develop during winter freezes and, therefore, that wind machines would be ineffective. Finally, there was uncertainty about the feasibility of operating frost protection devices at temperatures below $-15 \mathrm{C}$ from both human and machine perspectives.

By the late 1960s, Washington State Univ. (WSU) had made considerable progress in determining the critical temperature for peach flower buds (Proebsting, 1963; Proebsting and Mills, 1972) and some progressive peach growers/packers began testing winter heating. A significant step was taken when one packinghouse, Inland Fruit, established a laboratory to test the cold resistance of flower bud samples from growers' orchards. This provided growers with flower bud critical temperatures for their own locations and varieties.

Local information on flower bud critical temperatures during the winter is very important because critical temperatures change rapidly day-to-day (sometimes in hours) in response to ambient temperatures (Andrews and Proebsting, 1987; Proebsting, 1963; Proebsting and Mills, 1972). Orchard-toorchard variation in hardiness normally is relatively small (Proebsting and Mills, 1978), but can be very large if local weather permits thawing at some locations and not at-others.

Air temperature measurements up to 50 feet in the WSU orchard at Presser showed that inversions did develop during the spring, helping to start the investment in wind machines, but also showed that very strong in- versions could develop during the winter. Using the flower bud critical temperature data from WSU and, later, from the packinghouse, innovative growers learned that they could save crops by protecting them during the winter. By 1980, the practice was established sufficiently that winter freeze protection was listed as a production cost for peaches (Fagerlie and Folwell, 1980).

Five grower/packer organizations are now testing flower bud hardiness and reporting this information to the growers. Many growers are using this information for decisions about heating during the winter. Because air temperatures are so far below freezing, the operation is quite different from using the same equipment and concepts for protection during the spring (Proebsting, 1982).

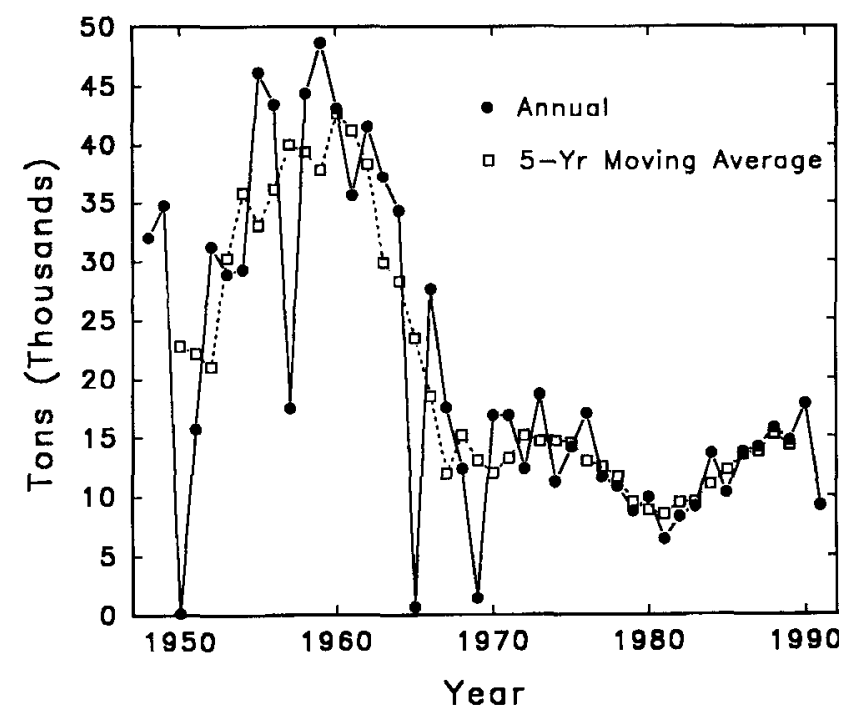

Annual Washington peach production with the moving average of the year plotted plus 2 years before and after, 194891.

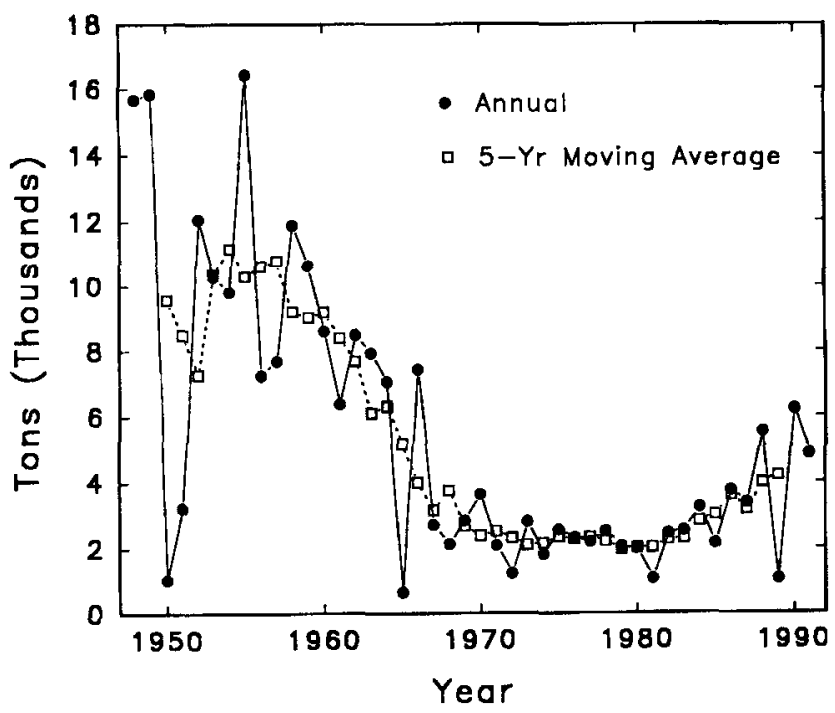

Fig. 2. Annual Washington apricot production with the moving average of the year plotted plus 2 years before and after, 1948-91. 
Fig. 3. Annual Washington sweet cherry production with the moving average of the year plotted plus 2 years before and after, 1948-91.

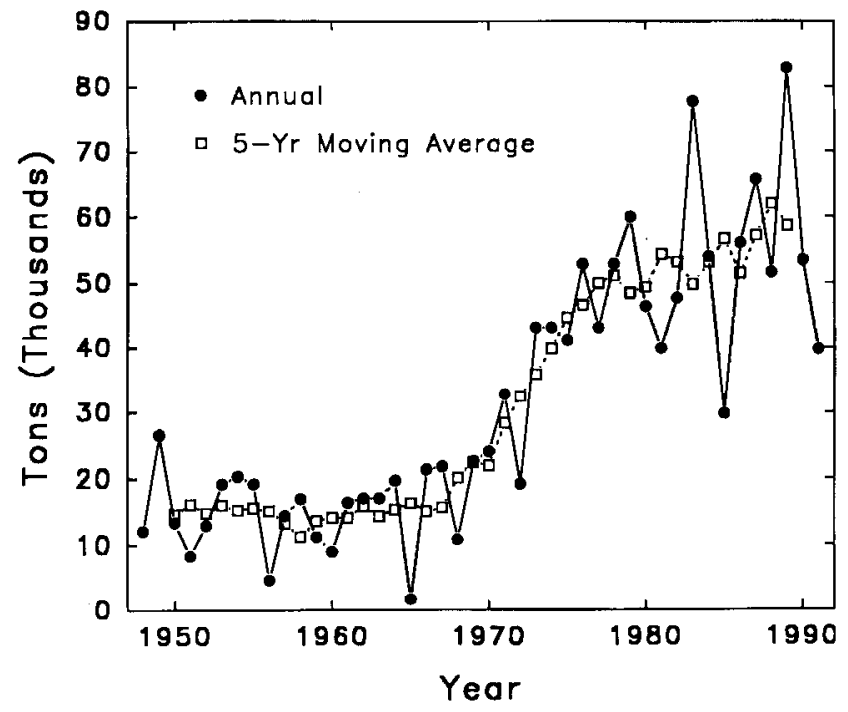

\section{Estimating flower bud critical temperatures}

A single critical temperature is a reasonable operational concept for spring freeze protection because damage to developing buds and fruit occurs over a narrow range of temperatures. As the trees approach bloom, a difference of only 1 to $2 \mathrm{C}$ exists between a full crop and no crop. This is not the case in midwinter freeze protection. During the winter, a difference of 3 to $4 \mathrm{C}$ or more would be required to have the same effect (Proebsting et al., 1966) (Fig. 4). With accurate critical temperatures from freeze testing, growers may attempt to manage temperatures to allow no bud mortality or, because peach and apricot trees produce far more flower buds than can be grown to marketable size and quality, to sacrifice up to $60 \%$ or $70 \%$ of the

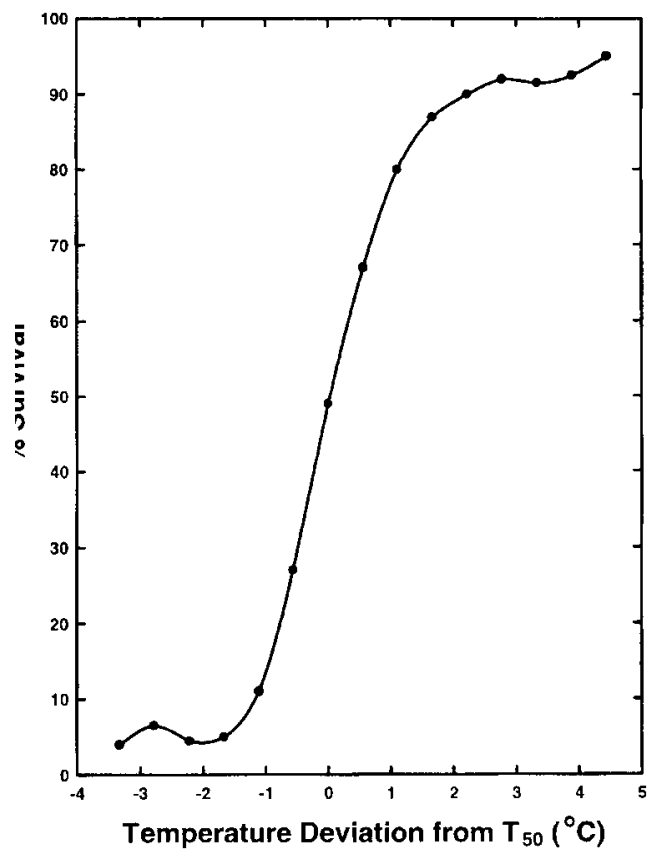

buds while still maintaining a commercial crop.

Cultivars vary in the amount of flower bud damage sustained at a given temperature, so the most-important cultivars for each grower or packinghouse are tested. These differences are perhaps most critical in late January and early February, as some cultivars complete their rest requirements and begin to develop and lose hardiness. Even without apparent visible developmental changes, there may be significant loss of hardiness, with resulting relative changes in hardiness among cultivars.

For most growers practicing mid-winter freeze protection, preparations begin in early fall. These growers estimate critical flower bud temperatures based on their experience in previous years. The estimates of critical temperatures are compared against specialized weather forecasts provided by the $\mathrm{Na}$ tional Weather Service. If forecasted temperatures approach these estimates, a freeze test is initiated to verify critical temperatures (Proebsting and Mills, 1971).

The freeze test begins with collecting 1to 2-year-old shoots representing the species and the type of fruiting wood that will remain after winter pruning. These samples are kept at ambient air temperature outside until they are placed in a specially constructed freeze chamber that is pre-set at outside air temperature. The thermostat controlling the temperature in the freeze chamber is programmed to lower the temperature 1 to $2 \mathrm{C} / \mathrm{h}$. The temperature is lowered until it reaches the highest temperature of a pre-determined critical temperature range. At selected temperatures within this range, the cooling is stopped and the shoots are held for 25 to $30 \mathrm{~min}$ at a constant temperature. A sample is then removed from the chamber. The removed shoots are allowed to thaw in a warm room for 45 to 60 rein, then the flower buds are sliced diagonally from the base to the tip to look for the characteristic browning (in the ovule of the flower primordium or pistil) that indicates injury. This process is generally repeated five to six times at successively colder temperatures. The results of these tests are presented to growers as an array of temperatures and associated bud mortalities. Critical temperatures are then established by each grower, who decides the maximum bud kill that will be allowed in their orchard. Protection is initiated when ambient temperatures approach this critical temperature.

\section{Operations}

Mid-winter freeze protection occurs at temperatures below $-15 \mathrm{C}$, requiring special preparation to assure safe, effective operation 
of equipment. Snow must often be removed from roads, driveways, and orchard heaters. Wind machines, the first line of defense in the winter, are usually run in the afternoon to ensure quick starts at near-critical temperatures later. Diesel-burning return stack heaters and propane and pressurized oil systems provide supplemental heat. Propane tanks require warming to maintain vapor pressure and flow at or near operational temperatures. Oil is more viscous than propane and harder to ignite.

Mid-winter freeze protection may begin in late afternoon or early evening-much earlier than during spring protection. Protection can be aided by the development of strong inversions under radiative freeze conditions or thwarted by advective (wind-driven) conditions, which render most protection systems ineffective. Long-time temperature data show that temperatures far below likely flower bud critical temperatures can occur. If temperatures are forecast to drop farther below critical than can be raised by the protection system, a decision not to protect that night might be appropriate. Most growers assume their efforts will be successful and operate systems even under severe conditions.

During the spring, most cold nights develop some inversion in the Yakima Valley; hence, the utility of wind machines and other frost protection systems. The inversions are less certain in the winter, but are frequent enough and ofien strong. Measurements of air temperatures at 1 and $20 \mathrm{~m}$ at the WSU Public Agricultural Weather System (PAWS) station (Wright and Ley, 1990), located in the WSU orchards at Presser, showed a 4C inversion on a night in late Feb. 1993, when temperatures below $-12 \mathrm{C}$ injured apricot buds. The inversion only reached $1.7 \mathrm{C}$ on the coldest, but nondamaging, night of the 199293 winter. Peach and cherry buds were injured by low temperatures in late Dec. 1991, with reduced yields in 1992. Apricots were not damaged in that incident. On that critical night, the inversion was $1.7 \mathrm{C}$ at the time of the lowest temperature.

\section{Refining critical temperature estimates}

While estimating the critical flower bud temperatures of individual orchards by packinghouses offers an insight into specific changes in stone fruit bud hardiness, it is a time- and labor-consuming process. Each freezing test takes two or three people a total of 8 to $10 \mathrm{~h}$ to complete, not including dissemination of the results to other interested growers. The individuals who do this testing usually have other job responsibilities within their organizations, which limits testing opportunities.

Dormant flower bud hardiness varies predictably in response to ambient temperatures (Proebsting and Mills, 1972), and thus is amenable to mathematical description and computerization. These relationships were described, tested, and validated for cherry (Andrews et al., 1987; Andrews and Proebsting, 1987) and peach (Proebsting et al., 1989). Using daily maximum and minimum temperatures, these simulations predict bud hardiness from late fall until the time when bud development begins in late winter. Once visible changes in bud development occur in the spring, growers use phenology charts that relate the stage of bud development to hardiness (Ballard et al. 1978) for use in spring freeze protection.

At present, these computer simulations are not being used by growers to supplement actual freeze testing. In a 1989 survey of fruit growers who routinely use weather-related management information, $95 \%$ of them ranked bud hardiness information as important to very important. If the validity of these simulations can be demonstrated adequately to key stone fruit growers, the simulations could provide real-time bud hardiness information, leading to more-accurate freeze tests and greater confidence about daily changes in bud hardiness between freeze tests. While simulations cannot provide all the information needed by those practicing winter freeze protection, they can provide additional information upon which to base management decisions.

\section{Essential infrastrueture and technological support}

In addition to the substantial efforts and interest by the five commercial organizations presently testing bud hardiness, other resources already exist to support and improve the decisionmaking process for mid-winter stone fruit freeze protection. Continued support for the agricultural weather forecasting programs of the National Weather Service is essential to providing specialized mid-winter temperature forecasts. A dense network of weather stations in south-central Washington (PAWS) is available to provide real-time weather data to growers via computer modem or touch-tone telephone. Although the bud hardiness simulation model has been shown to be accurate, it must be expanded to on-farm validation using weather data generated from the PAWS stations. Additional research is necessary to better understand and describe bud hardiness changes that occur as the trees complete rest (endodormancy). Finally, assisting growers who are freeze-test-

Mile simu-
cations
all the infer
mation needed by
those practicing
winter freeze
protection, they
can provide
additional
information
upon which to
base manage-
ment decisions.


ing to understand the implications of the variability of their test results and to improve field evaluation of bud kill after natural freezes will focus freeze protection decisions. At present, many organizations set critical temperatures high enough to avoid all bud loss. With relatively cheap fossil fuel prices, this may seem like an economic solution, but, as fuel costs rise, the protection of fruit that will later be thinned off may not be a wise use of resources.

\section{Present activities}

A project is underway to do this on-farm validation of bud hardiness simulations and to produce decision support software useful to stone fruit growers in central Washington. A key component of this project is to understand the scope of the tasks of and information needed by both the packinghouses conducting the freeze tests and the growers who are using this information, and to incorporate this information into a stone fruit bud hardiness decision support system.

\section{Literature Cited}

Andrews, P.K. and E.L. Proebsting. 1987. Effects of temperature on the deep supercooling characteristics of dormant and reacclimating sweet cherry flower buds. J. Amer. Soc. Hort. Sci. 112:334340 .

Andrews, P.K., E.L. Proebsting, and G.S. Lee. 1987. A conceptual model of changes in deep supercooling of dormant sweet cherry flower buds. J. Amer. Soc. Hort. Sci. 112:320-324.

Ballard, J.K. and E.L. Proebsting. 1978. Frost and frost control in Washington orchards. Washington State Univ. Coop. Ext. Serv. Ext. Bul. 634.

Ballard, J.K., R.B. Tukey, and E.L. Proebsting. 1978. Critical temperatures for blossom buds. Washington State Univ. Coop. Ext. Serv. Ext. Circ. 371, 373, 374.
Fagerlie, D.L. and R.J. Folwell. 1980. Establishment and production costs of a 40 -acre peach orchard in Washington. Washington State Univ. Coop. Ext. Serv. EM4563.

Fitch, J.B. 1992. Projections of fruit production in Washington for 1992 through 1996. Analysis for the Washington State Fruit Commission.

Proebsting, E. L., Jr. 1963. The role of air temperatures and bud development in determining hardiness of dormant 'Elberta' peach fruit buds. Proc. Amer. Soc. Hort. Sci. 83:259-269.

Proebsting, E.L. 1982. Cold resistance of stone fruit flower buds. Washington State Univ. Coop. Ext. PNW Bul. 221.

Proebsting, E., P. Andrews, A. Swindeman-Murphey, and $G$. Reisenauer. 1989. Forecasting hardiness for winter cold protection in peach orchards, $\mathrm{p}$. 159-166. In: P.H. Li (ed.). Low temperature stress physiology in crops. CRC Press, Boca Raton, Fla.

Proebsting, E.L. and H.H. Mills. 1971. The use of controlled freezing techniques for estimating critical temperatures for fruit buds. Washington Agr. Expt. Sta. Circ. 548.

Proebsting, E.L. and H.H. Mills. 1972. A comparison of hardiness responses in fruit buds of 'Bing' cherry and 'Elberta' peach. J. Amer. Soc. Hort. Sci. 97:802-806.

Proebsting, E.L. and H.H. Mills. 1978. A synoptic analysis of peach and cherry flower bud hardiness. J. Amer. Soc. Hort. Sci. 103:842-845.

Proebsting, E.L., H.H. Mills, and T.S. Russell. 1966. A standardized temperature-survival curve for dormant 'Elberta' peach fruit buds. Proc. Amer. Soc. Hort. Sci. 89:85-90.

Willett, M.J. and A.B. Peterson. 1987. Peach production in the arid Pacific Northwest. N.F. Childers and W.B. Sherman (eds. ). The peach: World cul tivars to marketing. Host. Publ., Gainesville, Fla.

Wright, M.A. and T. W. Ley. 1990. Washington Public Agricultural Weather System user manual. Washington State Univ. Coop. Ext. Serv. EB1547. 